Удк 664.15; 615.322

\title{
ПОЛУЧЕНИЕ ФРАКЦИЙ ОЛИГОСАХАРИДОВ И ИЗОФЛАВОНОИДОВ ИЗ СОЕВОЙ МЕЛАССЫ
}

\author{
() Н.В. Хабибулина ${ }^{1 *}$, А.А. Красночтанова ${ }^{1}$, Т.М. Бикбов ${ }^{2}$, В.В. Пономарев \\ ${ }^{1}$ Российский химико-технологический университет им. Д.И. Менделеева, \\ кафредра биотехнологии, Миусская пл., 9, Москва, 125047 (Россия), \\ e-mail: ernestine2007@ya.ru \\ ${ }^{2} 3 А О$ «Партнер-М», ул. Талалихина, 26, ГНУ Всероссийский научно- \\ исследовательский институт мясной промышленности им. В.М. Горбатова, \\ Москва, 109316
}

Подобраны технологические приемы для получения фракций олигосахаридов и изофлавоноидов из соевой мелассы: жидкость-жидкостная экстракция с использованием в качестве органической фазы этилацетата или $\mu$-бутанола с последующим ионным обменом на катионите C-150 MBН. Полученная фракция изофлавоноидов содержит от 20 до $60 \%$ основного вещества, фракция олигосахаридов содержит до $70 \%$ сахаров. Обе фракции могут быть использованы в различных отраслях промышленности.

Ключевые слова: соевая мука, меласса, изофлавоноиды, олигосахариды, экстракция, ионный обмен.

Настоящая работа выполнена при поддержке гранта Президента РФ для поддержки молодых российских ученых МК-4800.2014.4. Образцы соевой муки для исследований любезно предоставлены 3 АО «артнер-М».

\section{Введение}

Соевые бобы широко используются для производства белковых продуктов (мука, концентраты, изоляты). В то же время для удовлетворения спроса на белковые ингредиенты с развитыми функциональнотехнологическими свойствами и улучшенными медико-биологическими характеристиками необходимы новые технологические решения. В последние 10-15 лет были исследованы и подтверждены профилактические и лечебные свойства соевых пептидов, флавоноидов, олигосахаридов и других биологически активных соединений, содержащихся в семенах сои и продуктах их переработки. В связи с этим в настоящее время растет интерес к содержанию соответствующих биологически активных факторов в продуктах широкого потребления, к повышению их специфичности и созданию промышленных технологий их извлечения, очистки и концентрирования.

Флавоноиды - растительные полифенольные соединения, одной из подгрупп которых являются изофлавоноиды [1]. Изофлавоноиды - кислородсодержащие гетероциклы, содержащие скелет 3-фенил-

Хабибулина Наталья Викторовна - кандидат технических наук, ведущий инженер кафедры биотехнологии, e-mail: ernestine2007@ ya.ru Красноштанова Алла Альбертовна - доктор химических наук, доцент, профессор кафедры биотехнологии, e-mail: aak28@yandex.ru

Бикбов Тахир Мухаммедович - сотрудник, e-mail: partnermk@mail.ru

Пономарев Василий Васильевич - сотрудник, e-mail: partnermk@mail.ru хромана, который гидроксилирован по 4-му и 7-му положениям. Изофлавоноиды могут быть разделены на подгруппы в зависимости от уровня окисленности 3-фенилхроманового скелета. Основываясь на типе заместителя у 5 и 6 углеродных атомов, тремя формами агликонов, традиционно присутствующих в сое, являются даидзеин, генистеин и глицитеин. В сое изофлавоноиды встречаются в виде 7-О-гли-

\footnotetext{
* Автор, с которым следует вести переписку.
} 
козидов с тривиальными названиями даидзин, генистин и глицитин соответственно. Кроме того, все эти гликозиды могут быть этерифицированы по 6-О-положению гликозидного кольца ацетильной и малонильной группой, образуя шесть соединений, известных как ацетилдаидзин, ацетилгенистин, ацетилглицитин, малонилдаидзин, малонилгенистин и малонилглицитин. Т.е. соевые бобы содержат три вида изофлавоноидов, встречающихся в четырех химических формах [2-4].

Многочисленные исследования зарубежных ученых-диетологов показали, что продукты питания из сои обладают противоонкологическими свойствами за счет наличия в них антиканцерогенов нескольких классов, таких как изофлавоноиды и сапонины. Именно с употреблением продуктов, содержащих эти соединения, связывают снижение риска заболевания раком груди у женщин, раком желудка и другими онкологическими заболеваниями. Вывод о том, что соевые продукты играют чрезвычайно важную роль в деле предотвращения заболевания раком, подтверждается рядом статистических, медицинских и диетологических исследований $[5,6]$.

В медицине изофлавоны сои применяют как средство, понижающее артериальное давление, укрепляющее сердечно-сосудистую и нервную систему, сокращающее «приливы» в период менопаузы. Изофлавоны сои, обладающие фитоэстрогенным действием, нормализуют гормональный фон и тем самым предупреждают процессы, приводящие к бесконтрольному росту клеток (гиперпластические процессы) в организме человека, что препятствует возникновению злокачественных новообразований [7].

Традиционно для извлечения изофлавоноидов из растительного сырья в качестве экстрагентов используются органические растворители. В качестве последних наиболее широко применяют этанол и метанол различной концентрации, при этом температура экстракции может варьировать от комнатной до $125^{\circ} \mathrm{C}$, а продолжительность - от 40 мин до 2 ч [3, 8-11]. Для получения первичного экстракта растворимых компонентов сои используется водно-спиртовая экстракция (в качестве экстрагента применяют этанол с концентрацией 50-80\%). Процедуру экстракции повторяют 2-3 раза, заливая сырье новой порцией растворителя для более полного извлечения компонентов сырья. Затем объединенный экстракт обычно концентрируют под вакуумом, одновременно регенерируя растворитель. В зависимости от полноты удаления воды конечным продуктом может быть либо раствор экстрактивных веществ сои, либо соевая меласса.

Соевая меласса - коричневый вязкий сироп с горьковато-сладким запахом. Обычно соевая меласса содержит $50 \%$ сухих веществ. Она представляет собой совокупность различных соевых нутрицевтиков, а также олигосахаридов, состоит из углеводов (60\%), белков и других азотистых веществ (10\%), минеральных компонентов (10\%), жиров и соединений липидной природы (20\%). Основными составляющими соевой мелассы являются сахара, которые включают олигосахариды (стахиозу, раффинозу), дисахариды (сахарозу), небольшие количества моносахаридов (фруктоза, глюкоза).

Соевая меласса, полученная в процессе производства концентрата соевого белка, используется в промышленности с 1963 г. (Hayes Ashdod Ltd.) [12]. В настоящее время она находит применение в комбикормах или в жидких диетических смесях, в качестве компонента питательной среды при получении пребиотиков, для профилактики заболеваний, улучшения общего состояния. Соевая меласса наряду со стахиозой и раффинозой содержит фитоэстрогены, изофлавоноиды, сапонины, фитостерины, фитаты, ингибиторы Баумана - Бирк, фосфолипиды и фенольные кислоты. Следовательно, она может рассматриваться как богатый источник нутрицевтиков и олигосахаридов, которые являются полезными для профилактики и лечения различных патологических состояний. Кроме того, компоненты соевой мелассы могут быть использованы для местного наружного применения и в косметике. Изофлавоноиды, содержащиеся в мелассе, могут вызывать благоприятный эффект, действуя как антагонисты эстрогена и как антиандрогены, уменьшая распространение вредных клеток и проявляя антиоксидантное, противомикробное, антигрибковые и противовирусные свойства [13].

Меласса - углеводистый корм, содержащий около 60\% сахара, является востребованной на рынке ценной добавкой к кормам для животных и птицы. Перед скармливанием ее разбавляют теплой водой (из расчета 3-4 части воды на 1 часть мелассы), раствором поливают грубый корм и хорошо перемешивают [14].

Для приготовления питательных сред в микробиологической промышленности используют сырье минерального, животного и растительного происхождения, а также синтезированное химическим путем. Наиболее доступны для микроорганизмов углеводы, поэтому в лабораториях, а также во многих промышленных биотехнологических процессах (в производстве ферментов, антибиотиков, аминокислот и др.), используют глюкозу, сахарозу, лактозу и другие углеводы. Однако перечисленные углеводы являются цен- 
ным пищевым сырьем и достаточно дороги. В этой связи в большинстве крупнотоннажных микробиологических производств индивидуальные углеводы заменяют более доступными по стоимости продуктами: отходами крахмало-паточного производства (меласса, гидрол), гидролизатами торфа и растительных отходов, побочными продуктами молочной промышленности и др. В качестве субстрата для роста микроорганизмов меласса может быть использована для получения микробного белка [15], молочной и лимонной кислот [16], культивирования бифидобактерий с целью получения пробиотических препаратов [17], биоэтанола и биобутанола. В настоящее время интенсивно развиваются технологии производства автомобильного топлива - биоэтанола - из углеводсодержащего сырья и биодизеля - из масличных культур [18, 19].

Таким образом, соевая меласса является, с одной стороны, ценным продуктом за счет содержания большого количества олигисахаридов (являющихся источником углерода при ее использовании в качестве компонента питательной среды), с другой - недорогим источником изофлавоноидов, которые могут быть выделены из мелассы.

Очистку изофлавоноидов из раствора экстрактивных веществ сои можно вести различными способами. Этанольный экстракт без предварительного удаления из него этилового спирта можно обрабатывать органическими растворителями [20, 21], после чего фракцию, обогащенную изофлавоноидами, фракционировать с помощью гидрофобного сефадекса. Часто используется ультрафильтрация с последующим концентрированием полученного пермеата обратным осмосом [22] или ультрафильтрация с доочисткой пермеата методом жидкость-жидкостной экстракции [23, 24].

В других случаях мелассу разбавляют водой до адекватного содержания компонентов и подают на стадию ионного обмена. В качестве сорбентов обычно используют гидрофобные смолы (на основе поливинилбензола, метакрилата), на поверхности которых сорбируются изофлавоноиды. Десорбцию проводят однократно или ступенчато (с использованием, как правило, этанола и метанола разных концентраций) [25-30]. Ступенчатая элюция позволяет десорбировать разные группы изофлавоноидов раздельно. Далее, после удаления органического растворителя, реализуют стадии кристаллизации изофлавоноидов при низких температурах [31] или гидролиза получившейся фракции с применением соляной кислоты, щелочей или ферментов до образования агликонов [32, 33].

Таким образом, раствор экстрактивных веществ сои (меласса) может служить источником таких ценных компонентов, как изофлавоноиды и олигосахариды. Фракции, содержащие указанные компоненты, могут найти дальнейшее применение в различных отраслях промышленности: изофлавоноиды - при производстве биологически активных добавок, олигосахариды - прежде всего в микробиологической промышленности и кормопроизводстве.

Цель настоящей работы - получение из раствора экстрактивных веществ сои (мелассы) фракций изофлавоноидов и олигосахаридов.

\section{Экспериментальная часть}

Получение раствора экстрактивных веществ сои проводили из обезжиренной соевой муки по ГОСТ 3898-56 с содержанием сырого протеина $51 \pm 1,2 \%$ и содержанием сухих веществ $92 \pm 0,8 \%$. Содержание сухих веществ в образцах определяли по разнице массы навески после ее высушивания при температуре $105^{\circ} \mathrm{C}$ до постоянной массы в сухожаровом шкафу ШС-80-01. Содержание сырого протеина определяли микрометодом Къельдаля.

Соевую муку диспергировали в водно-этанольном растворе (концентрация этилового спирта - 70\%) до получения $10 \%$ суспензии в конической стеклянной колбе объемом 250 мл. Экстракцию проводили на магнитной мешалке ММ-5 при 700 об/мин. в течение 1 ч при комнатной температуре. Отделение раствора экстрактивных веществ от муки проводили центрифугированием в лабораторной центрифуге ОПН-8 в течение 10 мин при скорости вращения ротора 6000 об/мин.

Удаление этилового спирта из этанольного раствора осуществляли методом перегонки под вакуумом. Раствор помещали в круглодонную колбу, нагреваемую на водяной бане, колбу с помощью переходника Вюрца подсоединяли к прямому холодильнику с приемником дистиллята. Образующийся после удаления этанола водный раствор экстрактивных веществ сои дополнительно концентрировали на роторном испарителе с вертикальным холодильником до требуемого содержания сухих веществ.

Определение содержания общих сахаров в образцах проводили фенол-серным методом с использованием сахарозы в качестве стандарта. Определение содержания изофлавоноидов проводили по методике, 
описанной в [34], по реакции комплексообразования с хлористым алюминием. В качестве стандарта использовали дигидрокверцетин. рН растворов контролировали с помощью рН-метра рН-410 («Аквилон»).

Жидкость-жидкостную экстракцию проводили в стеклянных конических колбах объемом 50 и 100 мл при постоянном перемешивании на магнитной мешалке ММ-5 при 700 об/мин. После окончания экстракции эмульсию быстро переливали в делительную воронку, в которой происходило разделение фаз.

Ионный обмен проводили в аналитической колонке из плексигласа длиной 20 см и внутренним диаметром 1,5 см. Для прокачивания растворов через колонку использовали перистальтический насос PRECIFLOW (LAMBDA). Катионит перед применением переводили в рабочую форму ( $\left.{ }^{+}\right)$, оба ионита перед помещением в колонку промывали большим объемом дистиллированной воды до нейтрального $\mathrm{pH}$.

\section{Обсуждение результатов}

Как указывалось ранее, существующие технологические приемы нацелены на получение главным образом одного продукта: фракции соевых изофлавоноидов (ИФ) либо соевых олигосахаридов, в то время как их сочетание может позволить получить обе фракции с достаточной степенью чистоты и удовлетворительным выходом.

Из рассмотренных способов на первом этапе наиболее целесообразным является использование жидкость-жидкостной экстракции. В данном процессе за счет интенсивного эмульгирования водной фазы, содержащей целевые аналиты, в органической фазе, не смешивающейся (ограниченно смешивающейся) с водой, происходит перераспределение компонентов водной фазы в соответствии с их полярностью. В полученном после удаления этилового спирта растворе экстрактивных веществ соевой муки присутствуют, главным образом, соевые олигосахариды (65-70\% от содержания сухих веществ), растворимые в этаноле, и изофлавоноиды (1-1,5\% от содержания сухих веществ). Для получения отдельных фракций указанных компонентов в процессе жидкость-жидкостной экстракции были выбраны такие органические растворители, как этилацетат и $н$-бутанол. В ходе экспериментов изучались такие параметры, как соотношение органической и водной фаз, продолжительность экстракции, начальная кислотность водной среды.

Как можно видеть (табл. 1), при увеличении гидромодуля органического растворителя изофлавоноиды более полно извлекаются в органическую фазу. Однако для обоих исследуемых растворителей при увеличении содержания органической фазы наблюдается побочный эффект, связанный с частичным смешиванием этилацетата ( соотношениях органической и водной фаз, превышающих $1: 3$, не удавалось в лабораторных условиях достичь удовлетворительного разделения фаз. Кроме того, при этом наблюдается значительный переход компонентов углеводной природы в органическую фазу, что снижает чистоту получаемой фракции изофлавоноидов. В то же время, несмотря на большую эффективность экстракции изофлавоноидов в органическую фазу при увеличении ее объема, это сильно удорожает процесс. Исходя из вышеизложенного, в качестве рабочих соотношений водная фаза : органическая фаза были выбраны следующие: 1:3 - для этилацетата, $1: 1$ - для $н$-бутанола.

Таблица 1. Влияние соотношения органической и водной фаз на эффективность экстракции

\begin{tabular}{c|c|c|c}
\hline $\begin{array}{c}\text { Соотношение } \\
\text { водная фаза : органическая фаза }\end{array}$ & $\begin{array}{c}\text { Объем водной фазы после от- } \\
\text { деления, процент от исходного }\end{array}$ & $\begin{array}{c}\text { Сахара в водной фазе, } \\
\text { процент от исходного }\end{array}$ & $\begin{array}{c}\text { ИФ в водной фазе, } \\
\text { процент от исходного }\end{array}$ \\
\hline \multicolumn{3}{|c|}{ этилацетат } \\
\hline $1: 0,25$ & 100 & 96 & 78 \\
$1: 0,5$ & 98 & 94 & 65 \\
$1: 1$ & 93 & 94 & 60 \\
$1: 2$ & 89 & 93 & 50 \\
$\mathbf{1}: \mathbf{3}$ & $\mathbf{8 7}$ & $\mathbf{9 5}$ & 39 \\
$1: 5$ & 87 & 95 & 31 \\
$1: 7$ & 82 & 93 & 27 \\
$1: 10$ & 79 & 98 & 64 \\
\hline $1: 0,25$ & 99 & 96 & $\mathbf{4 3}$ \\
$1: 0,5$ & 92 & 75 & 59 \\
$1: 2$ & $\mathbf{7 3}$ & 55 & $\mathbf{5 1}$ \\
$1: 3$ & 50 & 25 & 32 \\
\hline
\end{tabular}


При увеличении продолжительности экстракции более 15 мин эффективность разделения существенно не меняется (табл. 2). Вероятнее всего, быстрое протекание процесса связано с интенсивным массообменном, идущим на границе раздела фаз. Разница полярностей сахаров и изофлавоноидов велика, поэтому скорость процесса определяется преимущественно площадью контакта капель водной и органической фаз, вследствие чего для эффективного протекания процесса необходимо поддерживать систему в состоянии эмульсии.

В кислых областях рН достигается наиболее полное извлечение ИФ в органическую фазу (табл. 3). Связано это, вероятнее всего, с тем, что в растворе экстрактивных веществ сои присутствуют различные формы изофлавоноидов (агликоны, гликозиды, малонильные и ацетильные конъюгаты). Для экстракции агликонов и гликозидов вследствие их низкой полярности наиболее пригоден этилацетат. Известно, что в присутствии соляной кислоты конъюгаты изофлавоноидов могут гидролизоваться до агликонов [32, 33]. Таким образом, подкисление водной фазы в настоящем процессе сопровождается изменением ее изофлавоноидного профиля (в сторону более простых форм - агликонов и гликозидов), что позволяет повысить эффективность экстракции этилацетатом. Повышение эффективности экстракции ИФ н-бутанолом в кислой области связано, вероятно, с протонированием функциональных групп изофлавоноидов и образованием водородных связей с ОН-группами бутилового спирта. На распределение сахаров между фазами рН существенно не влияет. Из представленных в таблице 3 данных можно сделать вывод, что при проведении жидкость-жидкостной экстракции водную фазу предварительно следует закислять до рН 2-3.

Таким образом, для осуществления жидкость-жидкостной экстракции были подобраны следующие условия:

1) При использовании этилацетата: соотношение водной и органической фаз - 1:3, продолжительность - 15 мин, рН 2-3. В таких условиях после разделения фаз водная фаза содержит 14\% ИФ, 94\% сахаров (от их содержания в исходном растворе), органическая фаза - 86\% ИФ, 6\% сахаров.

2) При использовании $н$-бутанола: соотношение водной и органической фаз - 1:1, продолжительность - 15 мин, рН 2-3. В таких условиях после разделения фаз водная фаза содержит $15 \%$ ИФ, $92 \%$ сахаров (от их содержания в исходном растворе), органическая фаза - 85\% ИФ, $8 \%$ сахаров.

Таблица 2. Влияние продолжительности экстракции на ее эффективность

\begin{tabular}{c|c|c}
\hline Продолжительность, мин & Сахара в водной фазе, процент от исходного & ИФ в водной фазе, процент от исходного \\
\hline \multicolumn{2}{c}{ этилацетат (соотношение 1:3) } \\
\hline 5 & 96 & 50 \\
10 & 94 & 46 \\
$\mathbf{1 5}$ & $\mathbf{9 5}$ & $\mathbf{3 9}$ \\
30 & 93 & 40 \\
45 & 96 & 37 \\
60 & 95 & 38 \\
\hline \multicolumn{3}{|c|}{ н-бутанол (соотношение 1:1) } \\
\hline $\mathbf{1 5}$ & 99 & 53 \\
30 & 94 & $\mathbf{4 9}$ \\
45 & $\mathbf{9 2}$ & 50 \\
60 & 91 & 50 \\
\hline
\end{tabular}

Таблица 3. Влияние рН водной фазы на эффективность экстракции

\begin{tabular}{c|c|c}
\hline $\mathrm{pH}$ & Сахара в водной фазе, процент от исходного & ИФ в водной фазе, процент от исходного \\
\hline \multicolumn{3}{c}{ этилацетат (соотношение 1:3) } \\
\hline $2,0-3,0$ & 96 & 18 \\
$6,0-7,0$ & 94 & 50 \\
$8,0-9,0$ & 87 & 70 \\
\hline \multicolumn{3}{c}{ н-бутанол (соотношение $1: 1)$} \\
\hline $2,0-3,0$ & 93 & 17 \\
$6,0-7,0$ & 90 & 54 \\
$8,0-9,0$ & 93 & 54 \\
\hline
\end{tabular}


Полученные данные, свидетельствующие об эффективном разделении компонентов по фазам, позволяют предположить, что использование органических растворителей возможно не только на стадии получения фракции изофлавоноидов из раствора экстрактивных веществ сои, но и на стадии их экстракции из соевой муки. Как было указано ранее, для получении первичного экстракта используется водно-этанольная смесь, в которую интенсивно экстрагируются как сахара (вследствие своей растворимости в воде), так и изофлавоноиды (вследствие хорошей растворимости в органических растворителях). В ходе дальнейших экспериментов была предпринята попытка экстрагирования отдельно изофлавоноидов из соевой муки. В качестве эталона использовали экстракт, полученный с использованием 70\%-го этилового спирта.

Первичные эксперименты показали, что при использовании чистых органических растворителей извлечения изофлавоноидов не происходит, в связи с чем дальнейшие эксперименты проводили с водноорганическими смесями. Поскольку этилацетат практически не смешивается с водой, добавление к нему воды не привело к увеличению эффективности экстракции. В случае использования н-бутанола в смеси с водой (табл. 4) вплоть до образования азеотропной смеси (42,5\% масс. $н$-бутанола) экстракция изофлавоноидов протекает на 30-40\%, сахаров - на 5-8\%. При превышении содержания воды в системе содержание сахаров в экстракте резко возрастает, а полученный экстракт после отделения муки расслаивается (табл. 4).

Однако, несмотря на невысокое содержание сахаров в получаемом экстракте, из сырья экстрагируется не более половины изофлавоноидов, что нельзя считать удовлетворительным результатом. Неясно также, какое влияние оказывает экстракция н-бутанолом на соевую муку. Традиционно из соевой муки после экстракции сахаров и изофлавоноидов этиловым спиртом получается белковый соевый концентрат, используемый в том числе в пищевой промышленности. $\boldsymbol{H}$-Бутанол с данной точки зрения является менее предпочтительным. В связи с этим получение фракций изофлавоноидов и сахаров из сои более целесообразно проводить из водно-этанольного раствора экстрактивных веществ.

Преимуществом использования на первом этапе жидкость-жидкостной экстракции является то, что полученные в настоящей работе закономерности реализуются вплоть до весьма высокого содержания сухих веществ в растворе экстрактивных веществ сои (соевая меласса). Так, показано, что до СВ 35\% эффективность разделения остается на том же уровне, что позволяет получить фракцию сахаров с высоким их содержанием - до 250 г/л. При такой концентрации меласса проще поддается хранению и транспортировке, в отличие от разбавленных растворов, получаемых при использовании иных методов. Недостатком жидкостьжидкостной экстракции можно считать недостаточно высокую степень очистки получаемой фракции изофлавоноидов (их содержание во фракции составляет порядка 25\%). Для повышения содержания биологически активных веществ во фракции можно использовать следующие методы дополнительной очистки.

Во-первых, возможно проведение жидкость-жидкостной экстракции в две и более стадий. При этом из органической фазы после проведения экстракции удаляют этилацетат или $\mu$-бутанол (что может быть достигнуто с помощью выпарки под вакуумом и использовании сильно гигроскопичных солей), разбавляют подкисленной до рН 2-3 водой до исходного объема, после чего проводят вторую стадию жидкостьжидкостной экстракции в подобранных ранее условиях.

Как следует из данных, представленных в табл. 5, повторная жидкость-жидкостная экстракция позволяет повысить чистоту получаемой фракции изофлавоноидов до 40\%, однако при этом вдвое возрастает расход органического растворителя, а также происходит потеря изофлавоноидов на стадии экстракции. Поэтому в качестве альтернативного варианта доочистки был использован метод ионного обмена.

Таблица 4. Эффективность экстрагирования ИФ и сахаров из соевой муки водно-бутанольными смесями различного состава

\begin{tabular}{c|c|c}
\hline $\begin{array}{c}\text { Соотношение вода/ } \text {-бутанол } \\
\text { (об./об.) }\end{array}$ & $\begin{array}{c}\text { Сахара в экстракте, процент от содержания } \\
\text { в водно-этанольном экстракте }\end{array}$ & $\begin{array}{c}\text { ИФ в экстракте, процент от содержания } \\
\text { в водно-этанольном экстракте }\end{array}$ \\
\hline $1: 19$ & 5,0 & 27,1 \\
$1: 9$ & 5,6 & 30,4 \\
$1: 5,7$ & 6,6 & 32,7 \\
$1: 4$ & 7,8 & 39,3 \\
$1: 2,3$ & 7,6 & 43,3 \\
$1: 1,5$ & 7,5 & 44,1 \\
$1: 1$ & 23,0 & 83,4 \\
\hline
\end{tabular}


Таблица 5. Двукратная жидкость-жидкостная экстракция (соотношение водной фазы и этилацетата $1: 3$, продолжительность 15 мин, $\mathrm{pH} 2-3$ )

\begin{tabular}{l|c|c|c}
\hline \multicolumn{1}{c|}{ Фракция } & Сахара, процент от исходного & ИФ, процент от исходного & Содержание ИФ, \% \\
\hline Водная фаза 1 & 94,9 & 21,9 & 26,3 \\
Органическая фаза 1 & 5,1 & 78,1 & 38,1 \\
Водная фаза 2 & 3,5 & 10,9 & 67,2 \\
Органическая фаза 2 & 1,6 & & 3 \\
\hline
\end{tabular}

Для ионного обмена изофлавоноидов можно использовать неполярные, слабополярные и сильнополярные смолы с соответствующей матрицей (полистирол-дивинилбензольная), на которой могут закрепиться изофлавоноиды. В качестве ионита в настоящей работе использовали смолу С150 МВН фирмы Purolite, отвечающую описанному выше требованию. Исследования в статическом режиме позволили подобрать оптимальный режим сорбции и десорбции с использованием указанной смолы в динамическом режиме:

- сорбция при соотношении катионита и фракции изофлавоноидов $1: 1$;

- рН фракции слабокислый (5-6);

- промывка одним объемом дистиллированной воды;

- десорбция двумя объемами 70\%-го этилового спирта.

Полученные результаты (табл. 6) свидетельствуют о необходимости стадии дополнительной промывки несорбировавшихся компонентов перед проведением десорбции. Видно, что потери изофлавоноидов, связывающихся гидрофобными взаимодействиями с матрицей смолы, при промывке водой не превышают $10 \%$, в то время как несорбированные сахара вымываются достаточно эффективно, и в спиртовую (десорбированную) фракцию при этом попадает 10-15\% сахаров от их общего содержания. Без промывки содержание сахаров в десорбате достигает 40\%. При использовании для десорбции двух объемов этилового спирта происходит практически полное извлечение изофлавоноидов с колонки. Степень чистоты полученного десорбата после обработки на катионите достигает 55-60\%.

С целью еще большего повышения качества продукта, как и в случае с жидкость-жидкостной экстракцией, был опробован метод многократного ионного обмена. В качестве исходного экстракта на второй и третьей стадии ионного обмена служила спиртовая фракция, полученная на предыдущей стадии десорбции. Спиртовая фракция была предварительно выпарена и разбавлена до исходного объема (табл. 7).

На каждой стадии сорбции-десорбции выход ИФ составляет порядка 75\% от их содержания в сорбируемом экстракте. При этом чистота полученных продуктов примерно одинакова (55-60\% по изофлавоноидам). Таким образом, степень сорбции и десорбции сахаров и изофлавоноидов на всех стадиях остается постоянной, что не позволяет повысить чистоту продукта, а, напротив, приводит к дополнительным потерям целевого продукта.

В литературе, посвященной очистке изофлавоноидов, часто встречается упоминание об использовании в этих целях смолы Amberlite XAD-4 [29, 30]. Как следует из спецификации, данная смола является гидрофобной, имеет полистирольную природу без дополнительных функциональных групп и подходит для разделения относительно гидрофобных молекул с невысокой молекулярной массой. В настоящей работе XAD-4 сравнивали с ранее подобранным катионитом C-150 (табл. 8).

Сорбция изофлавоноидов при использовании XAD-4 выше, также ниже потери изофлавоноидов на стадии промывки водой. Вероятно, это связано с образованием более прочных взаимодействий ИФ с данной смолой. Однако в силу этой же причины для десорбции изофлавоноидов с XAD-4 требуется не менее трех объемов 70\%-го этилового спирта, что увеличивает длительность процесса ионного обмена и стоимость расходных материалов. Кроме того, стоимость данного ионита выше, чем C-150.

Таблица 6. Влияние промывки на ионный обмен на катионите С-150

\begin{tabular}{c|c|c|c|c}
\hline \multirow{2}{*}{ Фракция } & \multicolumn{2}{|c|}{ Без промывки } & \multicolumn{2}{c}{ С промывкой } \\
\cline { 2 - 5 } & $\begin{array}{c}\text { ИФ, процент от } \\
\text { исходного }\end{array}$ & $\begin{array}{c}\text { Сахара, } \\
\text { процент от исходного }\end{array}$ & $\begin{array}{c}\text { ИФ, процент от } \\
\text { исходного }\end{array}$ & $\begin{array}{c}\text { Сахароцент от исходного } \\
\text { процоя }\end{array}$ \\
\hline Несорбированная (1V) & 19 & 61 & 18 & 63 \\
Промывная вода (1V) & - & - & 10 & 24 \\
Спирт 1V & 54 & 18 & 45 & 7,3 \\
Спирт 2V & 18 & 13 & 23 & 3,4 \\
Спирт 3V & 9 & 8 & 3 & 1,3 \\
\hline
\end{tabular}


Таблица 7. Трехкратный ионный обмен на катионите C-150

\begin{tabular}{l|c|c}
\hline \multicolumn{1}{c|}{ Фракция } & ИФ, процент от исходного & Сахара, процент от исходного \\
\hline Исходный экстракт & 100 & 61 \\
Несорбированная фракция 1 & 15 & 24 \\
Промывные воды 1 & 15 & 15,0 \\
Спиртовая фракция (десорбат) 1 & 70 & 3,5 \\
Несорбированная фракция 2 & 10 & 2,5 \\
Промывные воды 2 & 7,5 & 9,0 \\
Спиртовая фракция (десорбат) 2 & 52,5 & 2 \\
Несорбированная фракция 3 & 7,5 & 1,5 \\
Промывные воды 3 & 2,5 & 5,0 \\
Спиртовая фракция (десорбат) 3 & 40 & \\
\hline
\end{tabular}

Таблица 8. Содержание целевых компонентов во фракциях, получаемых при проведении ионного обмена на смолах C-150 и XAD-4

\begin{tabular}{l|c|c|c|c}
\hline \multirow{2}{*}{ Фракция } & \multicolumn{2}{|c|}{ Катионит С150 МBH, Purolite } & \multicolumn{2}{c}{ XAD-4, Amberlite } \\
\cline { 2 - 5 } & $\begin{array}{c}\text { ИФ, процент от ис- } \\
\text { ходного }\end{array}$ & $\begin{array}{c}\text { Сахара, } \\
\text { процент от исходно- } \\
\text { го }\end{array}$ & $\begin{array}{c}\text { ИФ, процент от ис- } \\
\text { ходного }\end{array}$ & $\begin{array}{c}\text { процент от исходно- } \\
\text { го }\end{array}$ \\
\hline Несорбированная (1V) & 20 & 60 & 11 & 55 \\
Промывная вода (1V) & 12 & 27 & 4 & 23 \\
Спирт 1V & 43 & 8 & 43 & 13 \\
Спирт 2V & 21 & 4 & 26 & 6 \\
Спирт 3V & 4 & 1 & 15 & 3 \\
\hline
\end{tabular}

\section{Выводы}

Изучен процесс получения фракций олигосахаридов и изофлавоноидов из раствора экстрактивных веществ сои. На первой стадии проводят жидкость-жидкостную экстракцию в течение 15 мин с предварительным подкислением раствора до $\mathrm{pH} 2-3$. В качестве органического растворителя используют этилацетат в соотношении 3:1 (органическая фаза : водная фаза) либо $н$-бутанол в соотношении 1:1. Возможно предварительное концентрирование раствора экстрактивных веществ сои до содержания сухих веществ $35 \%$, что позволит получить высококонцентрированную фракцию соевых олигосахаридов.

Полученная на стадии жидкость-жидкостной экстракции фракция изофлавоноидов имеет чистоту порядка 25\%. Для дополнительной очистки после отделения органического растворителя данную фракцию передают на стадию ионного обмена с использованием катионита C-150 MBH (Purolite). Проведение однократного процесса позволяется получить фракцию изофлавоноидов с чистотой 55-60\%, пригодную для использования в производстве биологически активных добавок.

\section{Список литературы}

1. Heinonen S-M., Wahala K., Adlercreutz H. Metabolism of isoflavones in human subjects // Phytochemistry Reviews. 2002. Vol. 1. Pp. 175-182.

2. Vasanthan Faraj H. Soybean isoflavones: effects of processing and health benefits // Food Reviews International. 2004. Vol. 20, N1. Pp. 51-75.

3. Luthria D.L., Biswas R., Natarajan S. Comparison of extraction solvents and techiques used for the assay of isoflavones from soybean // Food Chemistry. 2007. Vol. 105, Issue 1. Pp. 325-333.

4. Penalvo L., Nurmi T., Adlercreutz H. A simplified HPLC method for total isoflavones in soy products // Food Chemistry. 2004. Vol. 87, Issue 2. Pp. 297-305.

5. Messina M., Wood C. Soy isoflavones, estrogen therapy, and breast cancer risk: analysis and commentary // Nutrition Journal. 2008. Vol. 7, N17. 21 p.

6. Nestel P. Isoflavones: their effects on cardiovascular risk and functions // International Congress Series. May 2004. Vol. 1262. Pp. 317-319

7. Mishra P., Kar A., Kale R.K. Prevention of chemically induced mammary tumorigenesis by daidzein in pre-pubertal rats: the role of peroxidative damage and antioxidative enzymes // Molecular and Cellular Biochemistry. 2009. Vol. 325, N1-2. Pp. 149-157.

8. Pat. 6261565 (US) Method of preparing and using isoflavones / E. Gugger, M. Empie // 2001. July 17.

9. Cho S.Y., Lee Y.N., Park H.J. Optimization of ethanol extraction and further purification of isoflavones from soybean sprout cotyledon // Food Chemistry. 2009. Vol. 117, Issue 2. Pp. 312-317.

10. Zgórka G. Pressurized liquid extraction versus other extraction techniques in micropreparative isolation of pharmacologically active isoflavones from Trifolium L. species // Talanta. 2009. Vol. 79, Issue 1. Pp. 46-53. 
11. Pat. 7560131 (US). High solubility composition with high isoflavone concentration and process of producing same / S. Wanezaki, H. Araki // 2009, July 14.

12. Pat. 5097017 (US). Process for making soy protein concentrate / Arthur H. Konwinski // 1992. March 17.

13. Chajuss D. Soy Molasses: Processing and Utilization as a Functional Food // Soybeans as Functional Foods and Ingredients, AOCS Press, Champaign. Ill., USA, 2004. pp. 201-208.

14. Pat. № WO 1997007811 A1. A novel use of soy molasses / D. Chajuss // 1997. March 03.

15. Зипер А.Ф. Корма и кормление сельскохозяйственных животных. М., 2003. 139 с.

16. Gao Y., Li D., Liu Y. Production of single cell protein from soy molasses using Candida tropicalis // Annals of Microbiology. 2012. Vol. 62, Issue 3. Pp 1165-1172.

17. Montelongo J-L., Chassy B.M., McCord J.D. Lactobacillus salivarius for Conversion of Soy Molasses into Lactic Acid // Journal of Food Science. 1993. Vol. 58, Issue 4. Pp. 863-866.

18. Патент № 2227805 (RU). Способ производства питательной среды для культивирования бифидобактерий / Т.В. Бархатова, А.М. Лунев, О.И. Квасенков, В.А. Ломачинский // 2004, апрель 27.

19. Long C.C., Gibbons W.R. Conversion of soy molasses, soy solubles, and dried soybean carbohydrates into ethanol // Int J Agric, Biol Eng. 2013. Vol. 6, N1. Pp 62-68.

20. Siqueira P.F., Karp S.G., Carvalho J.C., Sturm W., Rodríguez-León J.A., Tholozan J-L., Singhania R., Pandey A., Soccol C.R. Production of bio-ethanol from soybean molasses by Saccharomyces cerevisiae at laboratory, pilot and industrial scales // Bioresource Technology. 2008. Vol. 99, Issue 17. Pp. 8156-8163.

21. Pat. 6033714 (US). Process for production of isoflavone fractions from soy / E. Gugger, R.D. Grabiel // 2000. March 7.

22. Pat. 5702752 (US). Production of isoflavone enriched fractions from soy protein extracts / E. Gugger, D.G. Dueppen // 1997, December 30.

23. Xu L., Kumar A., Lamb K., Layton L. Recovery of isoflavones from red clover flowers by a membrane-based process // Innovative Food Science \& Emerging Technologies. 2006. Vol. 7, Issue 3. Pp. 251-256.

24. Pat. WO 2004037020 (A1). Soy isoflavone concentrate process and product / S. Navpreet // 2004, May 6.

25. Pat. 6369200 (US). Soy isoflavone concentrate process and product / T.A. Dobbins // 2002. April 9.

26. Pat. 6670632 (US). Process for obtaining an isoflavone concentrate from a soy extract / A. Chaihorsky // 1997. September 23.

27. Pat. 5679806 (US). Process for the isolation and purification of isoflavones / B.L. Zheng, J.A. Yegge, D.T. Bailey, J.L. Sullivan // 1995. October 21.

28. Pat. 6703051 (US). Process for separating and recovering protein and isoflavones from a plant material / G.A. Bates, B.A. Bryan // 2004. March 9.

29. Pat. 7524526 (US). Process for producing high purity isoflavones / A.K. Hilaly, B. Sandage, J. Soper // 2009. April 28.

30. Gugger E., Grabiel R. Preparative isolation of isolavones from defatted soy flakes // Journal of liquid chromatography \& related technologies. 2007. Vol. 30, N 9-12. Pp. 1617-1640.

31. Pat. 4428876 (US). Process for isolating saponins and flavonoids from leguminous plants / J. Iwamura // 1984. January 31.

32. Pat. 6565912 (US). Production of isoflavone enriched fractions from soy protein extracts / E. Gugger, R. Grabiel // 2003. May 20.

33. Pat. 6706292 (US). Recovery of isoflavones from soy molasses / D.H. Waggle, B.A. Bryan // 2004. March 16.

34. Pat. 6146668 (US). Preparation of isoflavones from legumes / G.E. Kelly, J.L. Huang, M.G. Deacon-Shaw, M.A. Waring // 2000. November 14.

35. Velić D., Jokić S., Bucić-Kojić A., Bilić M., Planinić M., Velić N., Kresoja D. Mathematical modeling of total flavonoid compounds extraction from conventionally grown soybeans // 46th Croatian \& 6th International Symposium on Agriculture. Opatija, Croatia, 14-18.02.2011. Pp. 690-694. 
Habibulina N.V. ${ }^{I^{*}}$, Krasnoshtanova A.A. ${ }^{1}$, Bikbov T.M. ${ }^{2}$, Ponomarev V.V. ${ }^{2}$ THE RESULTING FRACTION OLIGOSACCHARIDES AND ISOFLAVONES FROM SOY MOLASSES

${ }^{I}$ Russian Chemical Technology University behalf D.I. Mendeleev, Department of Biotechnology, Miusskaya Sq., 9,

Moscow, 125047 (Russia) e-mail: ernestine2007@ya.ru

${ }^{2}$ Closed Joint Stock Company «Partner-M», Street. Talalikhina, 26, All-Russia Research Institute of Meat Industry

behalf V.M. Gorbatov, Moscow, 109316

Processing methods chosen for preparation of fractions of oligosaccharides, and isoflavones soy molasses: liquid-liquid extraction using an organic phase of ethyl acetate or n-butanol, followed by ion exchange on a cation exchanger C-150 MBN. The resulting isoflavone fraction comprises from 20 to $60 \%$ of the main substance, a fraction of the oligosaccharide contains up to $70 \%$ of sugars. Both fractions can be used in various industries.

Keywords: soybean meal, molasses, izoflavnoidy, oligosaccharides, extraction, ion exchange.

\section{References}

1. Heinonen S-M., Wahala K., Adlercreutz H. Phytochemistry Reviews, 2002, vol. 1, pp. 175-182.

2. Vasanthan Faraj H. Food Reviews International, 2004, vol. 20, no. 1, pp. 51-75.

3. Luthria D.L., Biswas R., Natarajan S. Food Chemistry, 2007, vol. 105, issue 1, pp. 325-333.

4. Penalvo L., Nurmi T., Adlercreutz H. Food Chemistry, 2004, vol. 87, issue 2, pp. 297-305.

5. Messina M., Wood C. Nutrition Journal, 2008, vol. 7, no. 17, 21 p.

6. Nestel P. International Congress Series, May 2004, vol. 1262, pp. 317-319

7. Mishra P., Kar A., Kale R.K. Molecular and Cellular Biochemistry, 2009, vol. 325, no. 1-2, pp. 149-157.

8. Pat. 6261565 (US). 2001.

9. Cho S.Y., Lee Y.N., Park H.J. Food Chemistry, 2009, vol. 117, issue 2, pp. 312-317.

10. Zgórka G. Talanta, 2009, vol. 79, issue 1, pp. 46-53.

11. Pat. 7560131 (US). 2009.

12. Pat. 5097017 (US). 1992.

13. Chajuss D. Soybeans as Functional Foods and Ingredients, AOCS Press, Champaign. Ill., USA, 2004. pp. 201-208.

14. Pat. № WO 1997007811 A1. 1997.

15. Ziper A.F. Korma i kormlenie sel'skohozjajstvennyh zhivotnyh. [Feeds and feeding of farm animals]. Moscow, 2003, 139 p. (in Russ.)

16. Gao Y., Li D., Liu Y. Annals of Microbiology, 2012, vol. 62, issue 3, pp. 1165-1172.

17. Montelongo J-L., Chassy B.M., McCord J.D. Journal of Food Science, 1993, vol. 58, issue 4, pp. 863-866.

18. Pat. 2227805 (RU). 2004. (in Russ.)

19. Long C.C., Gibbons W.R. Int J Agric, Biol Eng, 2013, vol. 6, no. 1, pp 62-68.

20. Siqueira P.F., Karp S.G., Carvalho J.C., Sturm W., Rodríguez-León J.A., Tholozan J-L., Singhania R., Pandey A., Soccol C.R. Bioresource Technology, 2008, vol. 99, issue 17, pp. 8156-8163.

21. Pat. 6033714 (US). 2000.

22. Pat. 5702752 (US). 1997.

23. Xu L.,. Kumar A, Lamb K., Layton L. Innovative Food Science \& Emerging Technologies, 2006, vol. 7, issue 3, pp. 251-256.

24. Pat. WO 2004037020 (A1). 2004.

25. Pat. 6369200 (US). 2002.

26. Pat. 6670632 (US). 1997.

27. Pat. 5679806 (US). 1995.

28. Pat. 6703051 (US). 2004.

29. Pat. 7524526 (US). 2009.

30. Gugger E., Grabiel R.. Journal of liquid chromatography \& related technologies, 2007, vol. 30, no. 9-12, pp. 1617-1640.

31. Pat. 4428876 (US). 1984.

32. Pat. 6565912 (US). 2003.

33. Pat. 6706292 (US). 2004.

34. Pat. 6146668 (US). 2000.

35. Velić D., Jokić S., Bucić-Kojić A., Bilić M., Planinić M., Velić N., Kresoja D. 46th Croatian \& 6th International Symposium on Agriculture. Opatija, Croatia, 14-18.02.2011. pp. 690-694. 